\title{
Hard Biodegradable Biopolymer Obtained from Whey Protein Concentrate and Montmorillonite
}

\author{
M. Kawecka-Radomska ${ }^{1}$ M. Tomczyńska-Mleko ${ }^{2}$ - M. Wesołowska-Trojanowska ${ }^{3}$. \\ K. Kowalczyk ${ }^{2} \cdot$ M. Chrząstek ${ }^{2}$ S. Mleko ${ }^{4}$
}

Published online: 12 April 2015

(C) The Author(s) 2015. This article is published with open access at Springerlink.com

\begin{abstract}
The aim of this study was to obtain whey protein concentrate-WPC/montmorillonite-MON biopolymers. Mixed whey protein/montmorillonite biopolymers were formed as heat-induced gels and hardened by water evaporation. Increase in protein concentration caused an increase in storage and loss moduli of the gels. Adding $5 \%$ of MON to whey protein gel matrix caused an increase in the moduli value. Obtained biopolymers behaved as weak physical gels as loss tangent was in a range $0.25-0.45$. Increase in protein concentration and addition of MON caused increase
\end{abstract}

S. Mleko

dairywhey@tlen.pl

M. Kawecka-Radomska

malgorzata.kaweckaradomska@up.lublin.pl

M. Tomczyńska-Mleko

martamleko@tlen.pl

M. Wesołowska-Trojanowska

marta.wesolowska-trojanowska@up.lublin.pl

K. Kowalczyk

krzysztof.kowalczyk@up.lublin.pl

M. Chrząstek

maria.chrzastek@up.lublin.pl

1 Institute of Soil Science and Environmental Development, University of Life Sciences in Lublin, Leszczyńskiego 7, 20-069 Lublin, Poland

2 Institute of Plant Genetics, Breeding and Biotechnology, University of Life Sciences in Lublin, Akademicka Street 15, 20-950 Lublin, Poland

3 Department of Biotechnology, Human Nutrition and Food Commodity Science, University of Life Sciences, Skromna 8, 20-704 Lublin, Poland

4 Department of Milk Technology and Hydrocolloids, University of Life Sciences in Lublin, Skromna 8, 20-704 Lublin, Poland in viscosity of the biopolymers measured by dissipation of ultrasound vibrations. Addition of MON generally caused reinforcement of the structure of the mixed gels and the material was more resistant to puncture. Addition of MON caused changes in the microstructure of whey protein gel, which became more fine-stranded. It was probably caused by adsorption of the ions by MON. Drying of WPC/MON gels caused formation of very hard biopolymer, which can be applied as natural biodegradable material.

Keywords Biodegradable - Biopolymer .

Montmorillonite $\cdot$ Rheology $\cdot$ Whey protein

\section{Introduction}

Synthetic polymers production is one of the leading industry in the world. Growing environmental concern causes increased interest in development of new biopolymers based on proteins, carbohydrates and lipids obtained from natural or agricultural sources. Additional value is added to biopolymers produced from agricultural and food industry by-products. Bioplastics from protein feedstock used as packaging, agriculture, horticulture and medical materials may have significant advantages over synthetic plastics [1]. Fast biodegradation ratio is the main advantage in production of natural biopolymers. Whey protein isolate films buried in a compost pile began to degrade in 2 days and more than $80 \%$ of total solids were lost in 7 days [2]. Because of their large potential for agricultural, industrial and medicinal applications, nanomaterials have been the focus of many researchers for the past few decades. Among them nanoclays are natural nanomaterials that occur in the soil, among which montmorillonite and allophane are the most important species [3]. Montmorillonite is a di-octahedral clay of which two 
third of its octahedral sites are mainly occupied by trivalent cations, that is, $\mathrm{Al}^{3+}$ or $\mathrm{Fe}^{3+}$. Most of the sites of the trioctahedral type are occupied by divalent cations, mostly $\mathrm{Mg}^{2+}$ [4]. Organically-modified montmorillonites formed by intercalation of quaternary ammonium cations, have long been used as rheological modifiers and additives in inks, paints and cosmetics and as delivery systems for the controlled release of drugs and nutraceutics [3]. Montmorillonite clays are widely used for various applications such as drilling fluid, adhesives, aerosols, animal and poultry food pelletization, barrier clays, bleaching earths, catalysts, cement, ceramics, cosmetics, detergents, emulsion stabilizers, fertilizers, food additives, paint, paper, pharmaceuticals, plastics, rubber, water clarification, construction, and adsorbents [5]. In recent years some attempts were made to produce different nanomaterials or biopolymers based on clays with addition of proteins or polysaccharides. Freezedried macroporous foams were prepared from an aqueous colloidal suspension of chitosan/xanthan gum $/ \mathrm{Na}^{+}$-montmorillonite nanoclay. The suspension after freezing formed a cryogel. This product was subsequently dried under vacuum condition to obtain porous foam materials [6]. Wheat gluten/montmorillonite nanocomposite films were obtained in a single screw-extruder using urea as a combined denaturant and plasticizer [7]. The thermoplastic starch and montmorillonite nanocomposite material was obtained by conventional extrusion method $[8,9]$.

There are no attempts described in the literature to obtain protein/montmorillonite nanocomposite materials using mild heating conditions. There are also no publications on clays/ whey protein biopolymers. The idea of the research was to create a method to incorporate montmorillonite into protein gel matrix and to obtain strong nanopolymer material.

\section{Experimental}

\section{Materials}

Whey protein concentrate-WPC with $80.0 \%$ protein and $3.4 \%$ minerals content (SM Spomlek, Radzyń Podlaski, Poland). Protein concentration was determined by the Kjeldahl procedure [10], minerals content was provided by the producer. Montmorillonite-MON with surface area 220-270 $\mathrm{m}^{2} \mathrm{~g}^{-1}$ based on the product specification (Sigma-Aldrich, Poznań, Poland).

\section{Methods}

\section{Samples Preparation}

Whey protein concentrate dispersions $(6.0 ; 7.0 ; 8.0 ; 9.0$ and $10.0 \% \mathrm{w} / \mathrm{w}$ ) without or with $5.0 \% \mathrm{w} / \mathrm{w}$ of montmorillonite were made by hydrating in distilled water using a magnetic stirrer. Dispersions were heated in water bath for $30 \mathrm{~min}$. at $80^{\circ} \mathrm{C}$. After heating the samples were immediately cooled down with cold tap water for $15 \mathrm{~min}$. Obtained biopolymers were stored at $7{ }^{\circ} \mathrm{C}$ for $20 \mathrm{~h}$. All the samples after storing were equilibrated at $21^{\circ} \mathrm{C}$ for $3 \mathrm{~h}$ and subjected to evaluations of their physicochemical properties and microstructure.

Samples with montmorillonite were dried in a thermostatic cabinet ST3/3 (Pol-Eko-Aparatura, Wodzisław Śląski, Poland) for $48 \mathrm{~h}$ at $35^{\circ} \mathrm{C}$.

\section{Dynamic Oscillatory Measurements}

Dynamic rheological measurements were performed using RS300 (ThermoHaake, Karlsruhe, Germany) rheometer with a serrated parallel steel plate geometry $(35 \mathrm{~mm}$ diameter, $2 \mathrm{~mm}$ gap size) to limit the potentiality of sliding effects. Samples were analyzed by frequency sweeps at $0.1-10 \mathrm{~Hz}$ range in linear viscoelastic region (at 0.01 strain evaluated previously by strain sweeps). All the measurements were performed at the temperature $21^{\circ} \mathrm{C}$.

\section{Ultrasound Viscosity Measurements}

An ultrasound viscometer Unipan type 505 (UNIPAN, Warsaw, Poland) probe was immersed into the samples. The value of viscosity $\times$ density in mPas $\times \mathrm{g} \mathrm{cm}^{-3}$ was measured. Each result has been shown as an average of six measurements.

\section{Puncture Tests}

The undried samples were analyzed using a TA.XT2i Texture Analyzer with a 25-kg load cell (Stable Micro Systems Ltd., Surrey, UK). A penetration test was performed by a $10 \mathrm{~mm}$ in diameter steel cylinder probe operated at a crosshead speed of $1 \mathrm{~m} \mathrm{~s}^{-1}$ and penetration distance of $30 \mathrm{~mm}$. Penetration force was evaluated as a maximum force on the curve. Six measurements were carried out for each test. For dried biopolymer samples the puncture test was performed using a $\mathrm{P} / 2 \mathrm{~N}$ needle probe. The samples were analyzed on a $15-\mathrm{mm}$ thick metal plate with a 10-mm diameter hole in the center and a crosshead speed of $1 \mathrm{~m} \mathrm{~s}^{-1}$. The thickness of the samples was $2.0 \mathrm{~mm}$ at the test area and it was measured using a micrometer with an accuracy of $0.01 \mathrm{~mm}$. Three measurements were carried out to obtain each result. Photographic pictures of the samples breakthrough were made using Macro mode of ELPH 130 IS Canon camera (Canon, Tokyo, Japan).

\section{Scanning Electron Microscopy (SEM)}

Samples of undried gels were fixed by immersion in $2.5 \%$ glutaraldehyde solution in $0.1 \mathrm{M}$ sodium cacodylate buffer. 
The samples were dehydrated in serial dilutions of ethanol and acetone and dried at the critical point in liquid carbon dioxide. Preparations were coated with gold using a vacuum evaporator EMITECH K550x (Emitech, Ashford, United Kingdom). Preparations were viewed and photographed using a scanning electron microscope VEGA II LMU (Tescan, Canberra, USA).

\section{Statistical Analysis}

Statistical analysis of results (standard deviation, analysis of variance) was performed using the statistical program STATISTICA 5.0 PL (StatSoft Polska, Warsaw, Poland). The significance of differences between means was determined using the Tukey's test at confidence level of $p \leq 0.05$ based on the least significant difference.

\section{Results and Discussion}

\section{Rheological Properties}

Figure 1 presents changes in storage modulus $\mathrm{G}^{\prime}$ and loss modulus $\mathrm{G}^{\prime \prime}$ of the WPC/MON biopolymers at different frequency. Increase in protein concentration caused an increase in the moduli value. Adding $5 \%$ of MON to whey protein gel matrix caused also an increase in the moduli value. Storage moduli values were for all investigated samples several times higher than loss moduli values. In all cases $\tan \delta$ was smaller than 1 and greater than 0.1 (Fig. 2). Obtained biopolymers could be characterized as weak gels, as they presented a structure between those of a concentrated biopolymer $(\tan \delta>1)$ and a true gel $(\tan \delta<0.1)$ [11]. Increased protein concentration and addition of montmorillonite decreased relaxation behavior of the bonds. At $6 \%$ protein concentration the highest values of $\tan \delta$ were observed. It was probably caused by a loosening of the intermolecular forces in gel matrix [12]. Fukushima et al. [13] observed that the addition of clays led to increases in elastic modulus. This was attributed to the reinforcing effect of dispersed fillers, which could hinder mobility of polymer chains in the amorphous phase. Figure 3 shows relation between storage modulus for WPC/ MON biopolymers measured at $10 \mathrm{~Hz}$ and protein concentration. A power low correlation was found with high determination coefficient $\left(\mathrm{R}^{2}=0.98\right)$. Increase in protein concentration caused increase in viscosity of the biopolymers measured by dissipation of ultrasound vibrations (Fig. 4). This method, similar to dynamic rheology allows the measurement at small strain values with no destruction of the samples. An exponential correlation was found between protein concentration and the product of dynamic viscosity and density measured by an ultrasound viscometer.

\section{Puncture Test}

Figure 5 shows puncture force for investigated WPC/MON biopolymers. Generally an increase in protein concentration resulted in higher force needed to puncture the sample. The relationship was not as regular as for small strain methods. Higher concentration of protein and MON addition caused higher packing of the gel structure and higher probability of interactions, which results in better rheological properties reflected by small strain methods. Higher packing of the polymer can cause higher irregularity in microstructure with weaker areas, which results in crack propagation. Addition of MON generally caused reinforcement of structure and the material was more resistant to puncture. Sothornvit et al. [14] found, that the tensile properties determined by tensile strength and percentage elongation at break were influenced by the incorporation of
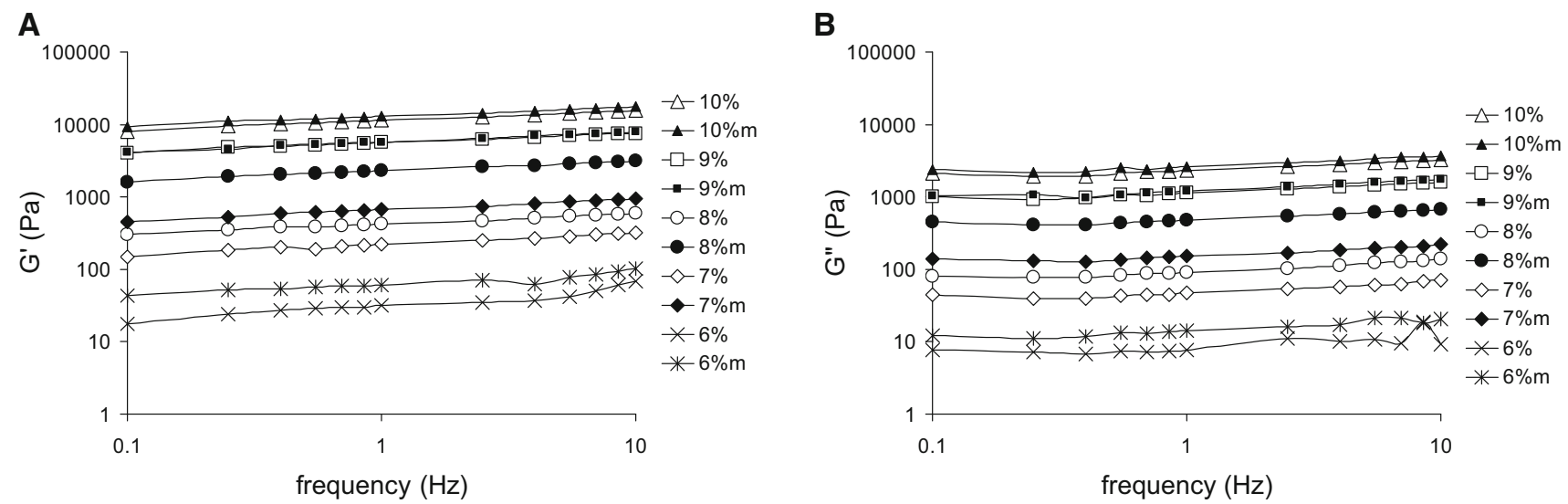

Fig. 1 Influence of frequency on storage modulus $-G^{\prime}$ (a) and loss modulus $-G^{\prime \prime}$ (b) for whey protein concentrate gels obtained at different protein concentration without or with $5 \%$ montmorillonite addition $(\mathrm{m})$ 
Fig. 2 Influence of frequency on $\tan \delta$ for whey protein concentrate gels obtained at different protein concentration without or with $5 \%$ montmorillonite addition (m)
Fig. 3 Effect of protein concentration in WPC/MON $\left(\mathrm{G}^{\prime}\right)$ measured at $10 \mathrm{~Hz}$ mixed gels on storage modulus
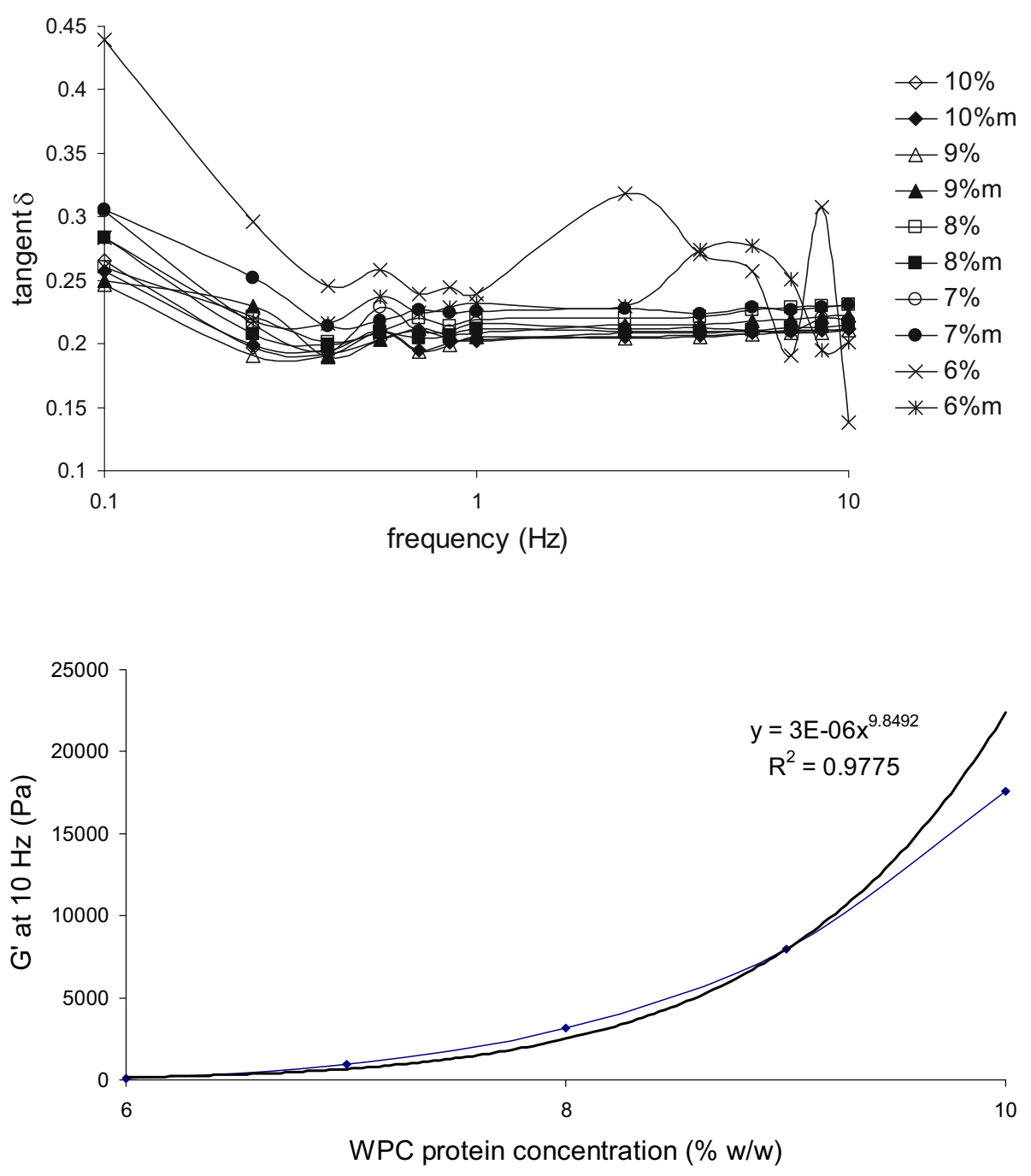

Fig. 4 Effect of protein concentration in WPC and WPC/MON mixed gels (m) on dynamic viscosity $\times$ density measured using ultrasound viscometer

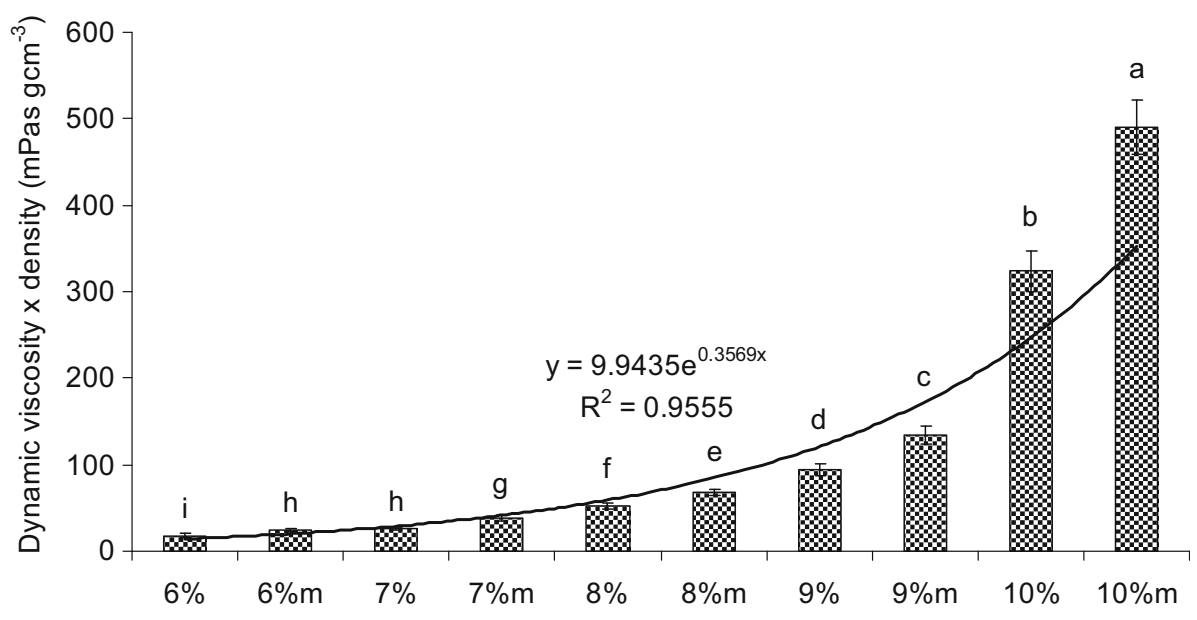

the organically modified MON. Fukushima et al. [13] showed that the addition of clays considerably increased the compressive strength and modulus of PBAT (poly(butylene adipate-co-terephthalate)). Verbeek and Klunker [15] found, that the Young's modulus of the various composites increased with increasing clay amount. 
Fig. 5 Effect of protein concentration in WPC and WPC/MON mixed gels (m) on puncture force

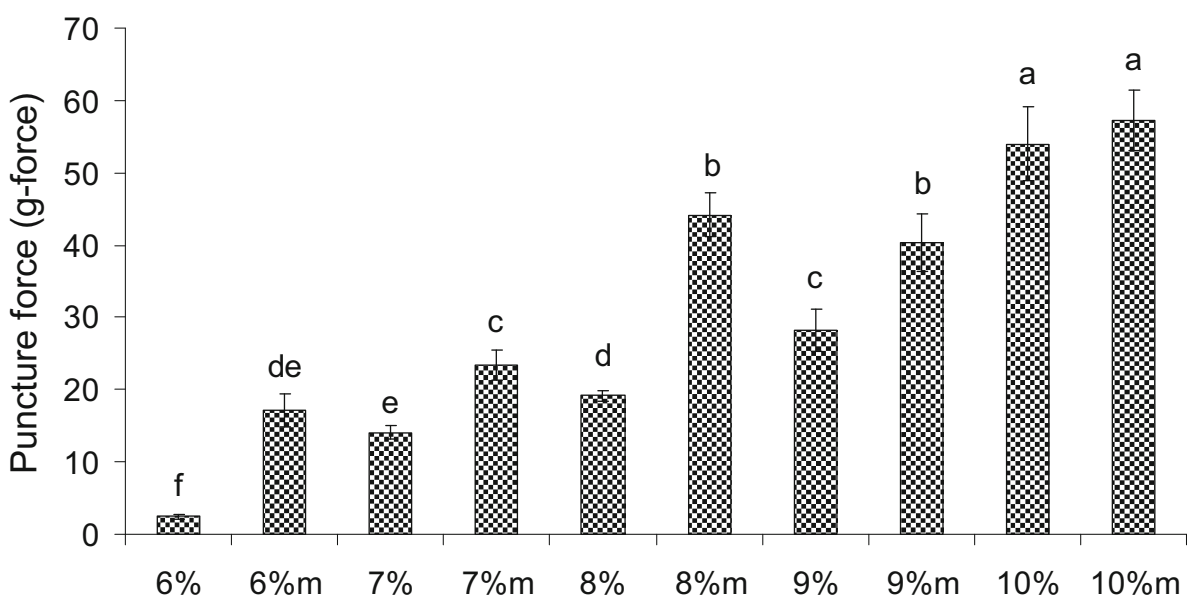

The stiffness of composites increased with the addition of fillers, and the extent to which this occurs depended on the surface area of the filler. Probably biopolymer chains are immobilized at the surface of the filler and strong affinity between the biopolymer and nano-clays leads to stiffening of the matrix [15].

Figure 6 presents representative curve for puncture test performed on dried WPC/MON biopolymer. No strain caused nonlinear changes were observed (no strain weakening or strain hardening) and there was a linear change in the force with increasing strain. At a critical force the structure was destroyed and a sudden drop in the force was observed. The breakthrough of the WPC/MON dried biopolymer obtained at $7 \%$ protein concentration and $5 \%$ MON had smooth and shiny surface (picture not shown), what is in an agreement with the shape of the puncture curve. No microcracks were observed which would cause strain-weakening behavior. The maximum puncture force was noted for biopolymers obtained at 7 and $8 \%$ concentration and the value was about $80 \mathrm{~N}$ (Fig. 7).
Investigated material was compared to the material tested with exactly the same methodology. Winkler and Margerison [16] assessed changes in the mechanical properties of bovine claw horn using puncture test by a $2 \mathrm{~mm}$ diameter needle, the same type as used in our research. Maximum puncture resistance observed by the researchers was about $25 \mathrm{~N}$. It means that the hardness of obtained WPC/MON biopolymer was more than 3 times higher than hardness of bovine claw horn. Undried biopolymer was soft and it was possible to form any shape. Drying caused formation of very strong material. Sharma and Luzinov [1] observed that ageing (water evaporation) during storage of protein biopolymers caused an increase in the mechanical properties of strength and stiffness.

\section{Microstructure}

Smooth breakthrough of the biopolymer is consistent with microstructure of obtained WPC/MON gels presented in Fig. 8. Addition of MON caused changes in the
Fig. 6 A curve representing changes of puncture force with travel distance of needle probe for dried WPC/MON biopolymer obtained at $7 \%$ protein concentration and $5 \%$ MON

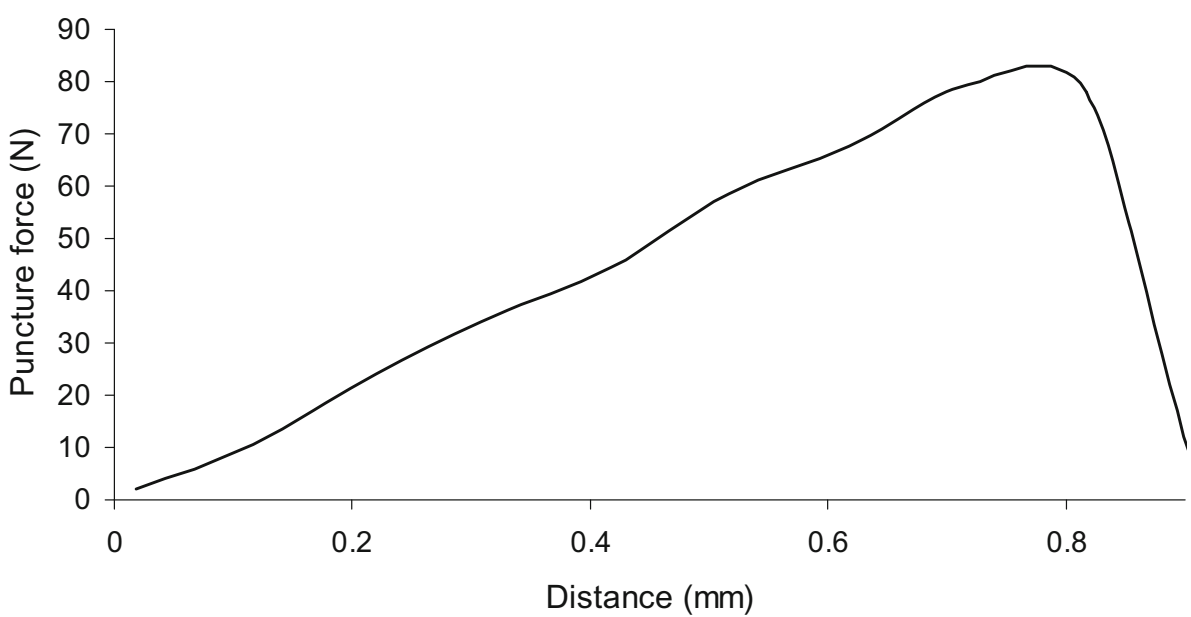


Fig. 7 Effect of protein concentration in WPC/MON gels on puncture force of dried biopolymers

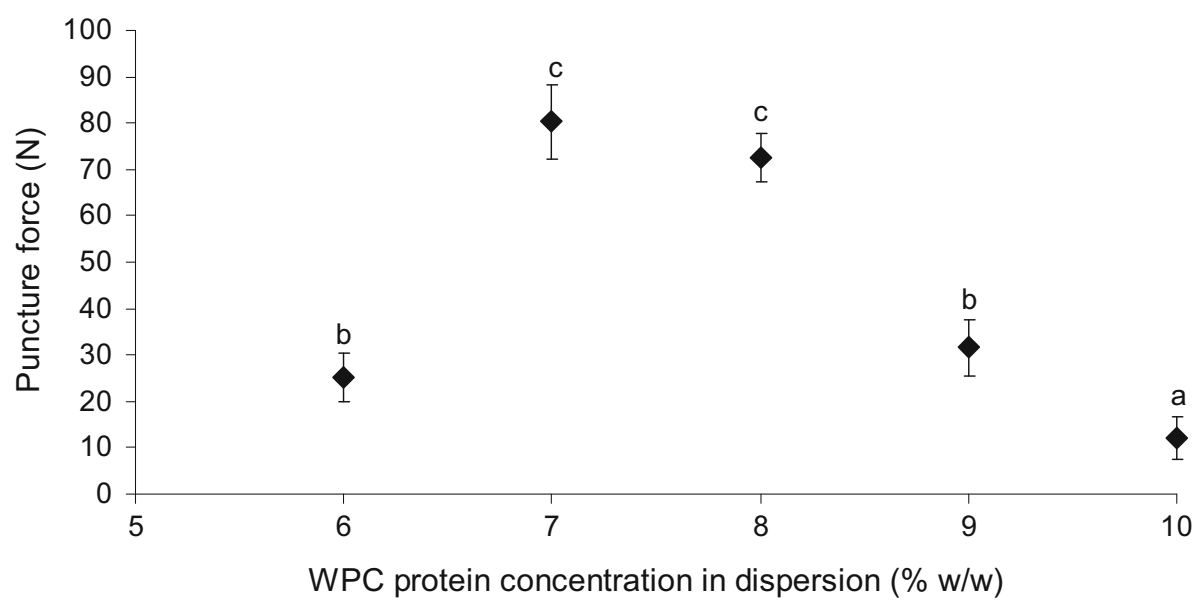

microstructure of whey protein gel, which became more fine-stranded. Clay minerals are good adsorbents for metal ions from aqueous solutions, owing to their high cation exchange capacity and high specific surface area associated with their small particle sizes [17]. Montmorillonite has a net negative charge of 0.8 unit per unit cell and this has been responsible for giving superior activity to montmorillonite as ions adsorbent [18]. Figure 9 shows microstructure of $7 \%$ protein WPC/MON biopolymer observed at higher magnification. Elongated structures are observed which are about $500 \mathrm{~nm}$ long and $150 \mathrm{~nm}$ wide. Cadene et al. [19] observed average dimensions for natural and synthetic MON as 320-400 nm long/250 nm wide and 200-250 nm long/120 nm wide, respectively. Round shaped edges of the montmorillonite crystals are probably from some interactions with protein molecules (Fig. 9). $\mathrm{X}$-ray diffraction data for the protein-kaolinite complexes showed that protein molecules were not intercalated in the mineral structure, but immobilized at the external surfaces and the edges of the kaolinite. Protein/clay microstructure appear to be influenced by electrostatic interactions, although steric effects should be also considered [20].

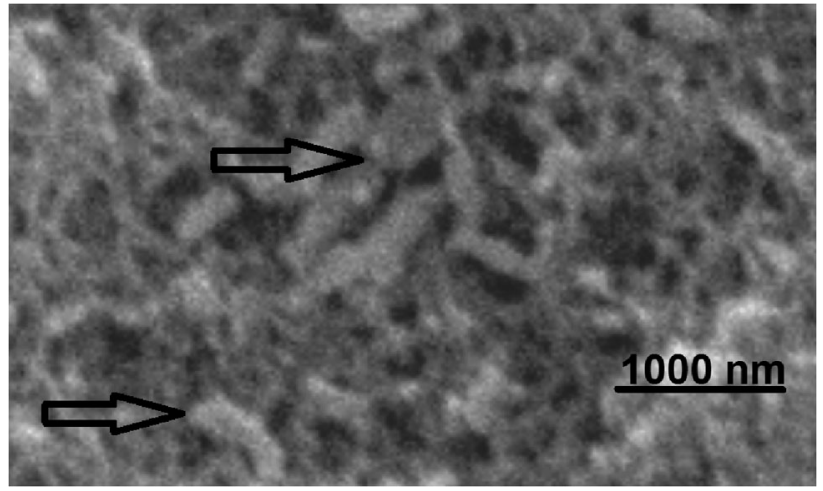

Fig. 9 SEM micrograph of $7 \%$ protein WPC/MON undried gel obtained with $5 \%$ montmorillonite (round shaped edges of the montmorillonite crystals were pointed out by arrows)

\section{Conclusions}

Results show a simple method to form mixed whey protein/montmorillonite biopolymers by obtaining heat-induced mixed gels and hardening them by water evaporation. Addition of MON generally caused
Fig. 8 SEM micrographs of $7 \%$ protein WPC/MON undried gel obtained without (a) or with (b) $5 \%$ montmorillonite
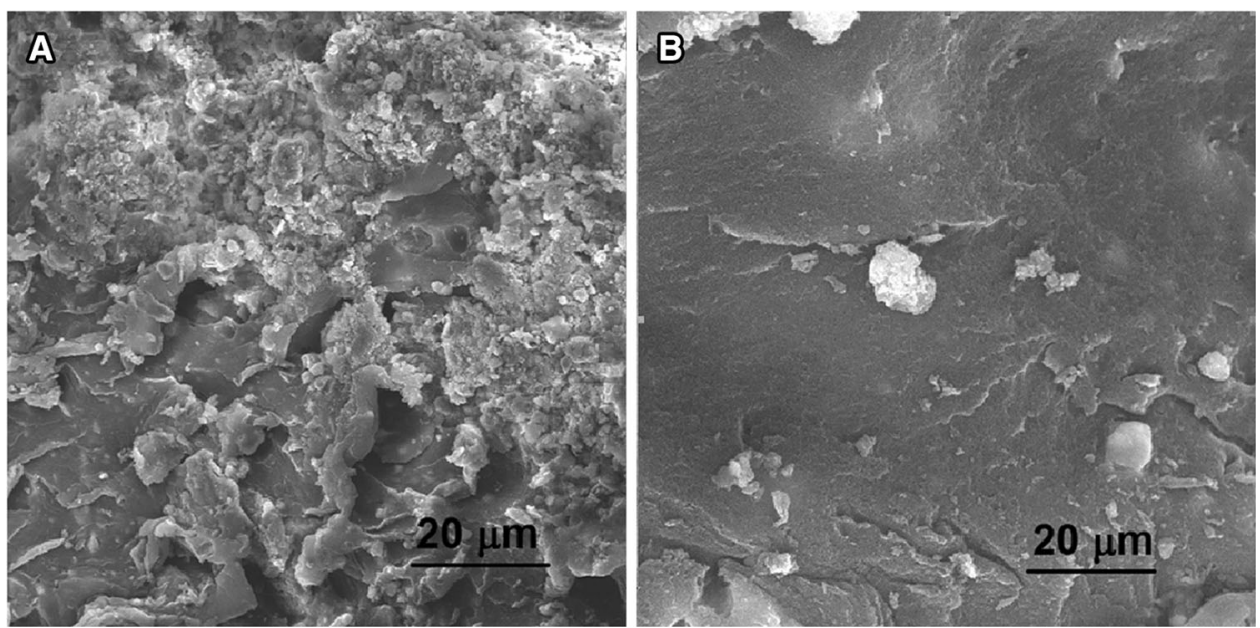
reinforcement of the structure and the material was more viscoelastic and resistant to puncture. Addition of MON caused changes in the microstructure of whey protein gel, which became more fine-stranded. It was probably caused by adsorption of the ions by MON. Drying of WPC/MON gels caused formation of very hard material. Obtained biopolymers are very natural, as after disposing in the ground, protein will be hydrolyzed by microbiological enzymes and montmorillonite will return to the soil.

Open Access This article is distributed under the terms of the Creative Commons Attribution 4.0 International License (http:// creativecommons.org/licenses/by/4.0/), which permits unrestricted use, distribution, and reproduction in any medium, provided you give appropriate credit to the original author(s) and the source, provide a link to the Creative Commons license, and indicate if changes were made.

\section{References}

1. Sharma S, Luzinov I (2012) Water aided fabrication of whey and albumin plastics characterization of extruded thermoplastic starch reinforced by montmorillonite nanoclay. J Polym Environ 20:681-689

2. Li J, Chen H (2000) Biodegradation of whey protein-based edible films. J Polym Environ 8:135-143

3. Floody MC, Theng BKG, Reyes P, Mora ML (2009) Natural nanoclays: applications and future trends-a Chilean perspective. Clay Miner 44:161-176

4. Madejova J (2003) FTIR techniques in clay mineral studies. Vibrat Spectrosc 31:1-10

5. Hayati-Ashtiani M (2012) Use of FTIR spectroscopy in the characterization of natural and treated nanostructured bentonites (montmorillonites). Part Sci Technol 30:553-564

6. Liu HH, Nakagawa K, Chaudhary D, Asakuma Y, Tade MO (2011) Freeze-dried macroporous foam prepared from chitosan/ xanthan gum/montmorillonite nanocomposites. Chem Eng Res Des 89:2356-2364

7. Ture H, Blomfeldt TOJ, Gallstedt M, Hedenqvist MS (2012) Properties of wheat-gluten/montmorillonite nanocomposite films obtained by a solvent-free extrusion process. J Polym Environ 20:1038-1045

8. Zhang Y, Liu Q, Hrymak A, Han JH (2013) Characterization of extruded thermoplastic starch reinforced by montmorillonite nanoclay. J Polym Environ 21:122-131

9. Ren P, Shen T, Wang F, Wang X, Zhang Z (2009) Study on biodegradable starch/OMMT nanocomposites for packaging applications. J Polym Environ 17:203-207

10. AOAC Official Method 960.52. (1995) Microchemical determination of nitrogen. Micro-Kjeldahl method. In: Official methods of analysis of Association of Official Analytical Chemists, 15th edn. AOAC, Arlington

11. Dolz M, Hernandez MJ, Delegido J (2006) Oscillatory measurements for salad dressings stabilized with modified starch, xanthan gum, and locust bean gum. J Appl Polym Sci 102:897-903

12. Lucey JA, Tamehana M, Singh H, Munro PA (2000) Rheological properties of milk gels formed by a combination of rennet and glucono- $\delta$-lactone. J Dairy Res 67:415-427

13. Fukushima K, Rasyida A, Yang M-Ch (2013) Biocompatibility of organically modified nanocomposites based on PBAT. J Polym Res 20:302

14. Sothornvit R, Hong S-I, An DJ, Rhim J-W (2010) Effect of clay content on the physical and antimicrobial properties of whey protein isolate/organo-clay composite films. Food Sci Technol 43:279-284

15. Verbeek CJR, Klunker E (2013) Thermoplastic protein nanocomposites using bloodmeal and bentonite. J Polym Environ 21:963-970

16. Winkler B, Margerison JK (2012) Mechanical properties of the bovine claw horn during lactation. J Dairy Sci 95:1714-1728

17. Abollino O, Giacomino A, Malandrino M, Mentasti E (2008) Interaction of metal ions with montmorillonite and vermiculite. Appl Clay Sci 38:227-236

18. Bhattacharyya KG, Gupta SS (2008) Adsorption of a few heavy metals on natural and modified kaolinite and montmorillonite: a review. Adv Colloid Interface Sci 140:114-131

19. Cadene A, Durand-Vidal S, Turq P, Brendle J (2005) Study of individual Na-montmorillonite particles size, morphology, and apparent charge. J Colloid Interface Sci 285:719-730

20. Barral S, Villa-Garcia MA, Rendueles M, Diaz M (2008) Interactions between whey proteins and kaolinite surfaces. Acta Mater 56:2784-2790 